\title{
The Effectiveness of M.D-Risti Application as an Alternative for Independent Early Detection of Risk of Pregnancy during the Pandemic COVID-19 in Palu City, Central Sulawesi, Indonesia
}

\author{
Ketut Suarayasa ${ }^{1 *}$, Elli Yane Bangkele ${ }^{1}$, Sumarni Sumarni ${ }^{2}$, Haerani Harun ${ }^{3}$, Bohari Bohari ${ }^{4}$ \\ ${ }^{1}$ Department of Public Health, Faculty of Medicine, Tadulako University, Palu, Indonesia; ${ }^{2}$ Department of Nutrition, Faculty of \\ Medicine, Tadulako University, Palu, Indonesia; ${ }^{3}$ Department of Clinical Pathology, Faculty of Medicine, Tadulako University, \\ Palu, Indonesia; ${ }^{4}$ Department of Nutrition, Faculty of Medicine, Universitas Sultan Ageng Tirtayasa, Banten, Indonesia
}

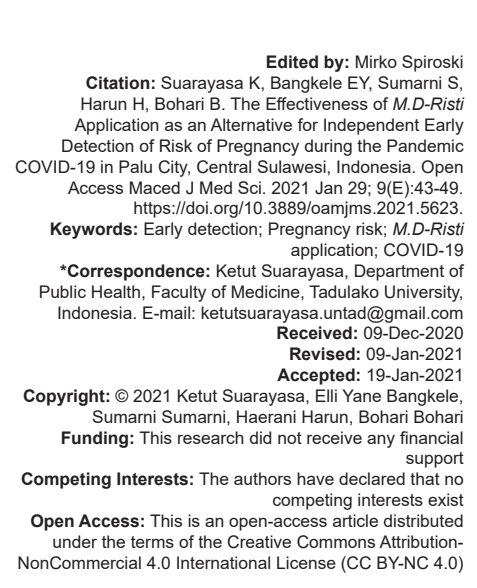

Introduction

The World Health Organization (WHO) estimates that $15-20 \%$ of pregnant women in both developed and developing countries will experience a high risk (risti) and/or complications [1]. The WHO also reports that the main causes of maternal death are bleeding, eclampsia, and infection, which may contribute to $60 \%$ of total maternal deaths. This condition can be prevented if early detection of risk factors for pregnancy is adequate during antenatal care [2], [3]. This is following the SDGs 3.1 target, which is to reduce the global maternal mortality rate to $70 / 100,000$ live births by 2030 . This target also continues the program of the MDGs target $5 \mathrm{a}$, which is to reduce $75 \%$ of the maternal mortality rate from 1990 to 2015 [4]. The maternal mortality rate is an indicator that reflects maternal health status, especially the risk of maternal death during pregnancy and childbirth [5].

The period of pregnancy is a time of prone health, both the health of the pregnant mother and the fetus she is carrying. Therefore, regular pregnancy checks from an early age (Antenatal Care) need to be done to be able to detect abnormalities/disorders/ illnesses suffered by pregnant women early [6], [7]. Antenatal care that is carried out regularly is also useful to facilitate a trusting relationship between pregnant women and health workers so that a sense of mutual responsibility grows to maintain a healthy pregnancy until the birth process [8].

Several risk factor approaches to preventing maternal mortality have been developed in Indonesia [9]. Factors 4 too and 3 too late are risk factor concepts that have been known for a long time in Indonesia [6]. Likewise, the Poedji Rochjati Score Card has been used in general in Indonesia, especially in Central Sulawesi, to detect early pregnancy risk factors that can adversely affect pregnant women and the fetus they are carrying.

So far, the responsibility for pregnancy "seems" only to the midwife. There are still many pregnant women who perceive the midwife's efforts to come to the Posyandu (Integrated Healthcare Center) for the examination of pregnant women, 
collect mothers in the class of pregnant women, carry out early detection of pregnancy risks, are only "obligations" of health workers, not a need for pregnant women. In the case of early detection of a high risk of pregnancy, the midwife conducts a checklist with the Pudji Rochyati Score Card, notifies the results to pregnant women, and keeps the scorecard at the health center. Storage the results of this checklist at the health center are intended to keep the card not lost or do not forget to take during pregnancy to control her pregnancy. However, on the other hand, it reduces the independence of pregnant women in managing their pregnancies. Therefore, it is necessary to develop independent high-risk pregnancy detection efforts, which are carried out by pregnant women themselves. Start doing the assessment, obtain and read the result, and save the result [10], [11].

During the current COVID-19 pandemic, the figures for maternal and child health service (ANC) coverage have decreased. In the conditions of the COVID-19 pandemic, several African countries have changed their routine ANC visits by giving a gap in the number of visits once every 3 months, starting with monthly visits and postponing postpartum visits 3 months after delivery [12]. Another study revealed that there was a significant decrease in the second ANC visit from $69.8 \%$ to 67.9 although it increased until March 2019 and March 2020 [13].

With the inactivity of several Posyandu (Integrated Healthcare Center) and classes for pregnant women, the number of contact between midwives and pregnant women has also decreased. Innovative efforts are needed to overcome this condition. Where pregnant women can still know the condition of their pregnancy, with a minimum frequency of visits to health services. One of them is through web-based applications that are widely developed today [14].

The M.D-Risti (high-risk detection mobile) application is a web-based application that contains a checklist of high-risk factors for pregnancy according to the Pudji Rochyati Score. Pregnant women will assess their risk factors by filling out the checklist on the application. After completing the assessment using the checklist, pregnant women will immediately get information about the amount of risk (risk score) and the actions that must be taken. Pregnant women will also be able to save the results on the mobile phone. The application will also be equipped with attractive and easy-to-understand features for pregnant women and a module that contains information about the importance of early detection of high risks, complications that can occur, and efforts to prevent them.

Based on the description above, this study aims to assess the knowledge, attitudes, actions, and skills of pregnant women in early detection of highrisk pregnancies before and after the intervention and the effectiveness of the M.D-Risti module and application.

\section{Methods}

This research used quantitative research with a quasi-experimental research design and using a pretest-post-test design, non-equivalent control group design. The intervention group was given treatment in the form of giving modules and the application of M.D Risti to pregnant women with the help of a health center midwife as an enumerator, while the control group did not give any treatment. The research location was in Palu City with 4 health centers (Puskesmas), namely, Mamboro Health Center, Talise Health Center, Taweli Health Center, and Pantoloan Health Center.

The population in this study were all pregnant women in Palu City with the sampling technique using purposive sampling, about 43 respondents for each group where only pregnant women who had Android phones could participate in this study. The independent variables of the study were the provision of modules and the application of M.D-Risti and the dependent variable was the knowledge, attitudes, actions, and skills of pregnant women in high-risk early detection. Data analysis was in the form of univariate analysis as a description of the knowledge, attitudes, actions, and skills of pregnant women in the intervention and control groups. Bivariate analysis was used to determine the differences in the pre-test and post-test for each group using the Wilcoxon test, while the Mann-Whitney test was used to determine the differences between groups.

\section{Results}

\section{Respondent characteristics}

Table 1 shows that most of the pregnant women who became respondents were 20-35 years old (85\%), completed high school education level (52\%), not working $(79 \%)$, and part of Kaili ethnics (74\%). Most of these pregnant women chose Puskesmas (Public Health center) as a place for their pregnancy checks (57\%), followed by Posyandu (Integrated Healthcare Center) (20\%). Most of the pregnant women who were selected as respondents had their first antenatal care examination in the first trimester $(64 \%)$. However, the frequency of antenatal care of respondents was mostly $<4$ times $(64 \%)$, because most of their gestational age had not yet reached the third trimester. This meant that they still had the opportunity to do the next antenatal care examination.

\section{Univariate analysis}

Table 2 shows that the level of knowledge of pregnant women in the intervention group had 
Table 1: Characteristics of respondents in the intervention group and the control group

\begin{tabular}{|c|c|c|}
\hline Variable & $\mathrm{n}$ & $(\%)$ \\
\hline \multicolumn{3}{|l|}{ Ages } \\
\hline$<20$ & 2 & 2 \\
\hline $20-35$ & 85 & 85 \\
\hline$>35$ & 13 & 13 \\
\hline \multicolumn{3}{|l|}{ Education } \\
\hline Elementary School & 7 & 7 \\
\hline Junior High School & 14 & 14 \\
\hline Senior High School & 52 & 52 \\
\hline College/Universities & 27 & 27 \\
\hline \multicolumn{3}{|l|}{ Occupation } \\
\hline Working & 21 & 21 \\
\hline Not working & 79 & 79 \\
\hline \multicolumn{3}{|l|}{ Ethnics } \\
\hline Kaili & 74 & 74 \\
\hline Java & 4 & 4 \\
\hline Bugis & 14 & 14 \\
\hline Etc & 8 & 8 \\
\hline \multicolumn{3}{|l|}{ ANC Place } \\
\hline Puskesmas (Public Health Center) & 57 & 57 \\
\hline Posyandu (Integrated Healthcare Center) & 20 & 20 \\
\hline Dokter Praktek (Independent Practitioner) & 2 & 2 \\
\hline Pustu (Auxiliary Health Center) & 9 & 9 \\
\hline Polindes (Village Polyclinic) & 2 & 2 \\
\hline Poskesdes (Village Health pPost) & 10 & 10 \\
\hline \multicolumn{3}{|l|}{ First ANC } \\
\hline Trimester I & 64 & 64 \\
\hline Trimester II & 27 & 27 \\
\hline Trimester III & 9 & 9 \\
\hline \multicolumn{3}{|l|}{ ANC Visit } \\
\hline Good $(\geq 4)$ & 36 & 36 \\
\hline Less $(<4)$ & 64 & 64 \\
\hline
\end{tabular}

increased knowledge of pregnant women about early detection of pregnancy risk in the good category from $6 \%$ (pre-test) to $32 \%$ (post-test). Likewise, the variable attitudes, actions, and skills for early detection also increased from pre-test to post-test. Although most of the respondents' knowledge level was in the sufficient category ( $60 \%$ on the post-test), they had good attitudes ( $88 \%$ on the post-test), good action ( $96 \%$ on the posttest), and good skills in early detection of pregnancy (90\% on post-test).

Table 2: Knowledge, attitudes, actions, and skills for early detection of risk of pregnancy in the intervention group for pregnant women in Palu city, 2020

\begin{tabular}{|c|c|c|c|c|}
\hline \multirow[t]{2}{*}{ Variables of Intervention Group } & \multicolumn{2}{|c|}{ Pre-test } & \multicolumn{2}{|c|}{ Post-test } \\
\hline & $\mathrm{N}$ & $(\%)$ & $\mathrm{N}$ & $(\%)$ \\
\hline \multicolumn{5}{|l|}{ Knowledge about RISTI detection } \\
\hline Well & 3 & 6 & 16 & 32 \\
\hline Enough & 24 & 48 & 30 & 60 \\
\hline Less & 23 & 46 & 4 & 8 \\
\hline \multicolumn{5}{|l|}{ Attitude toward Risti detection } \\
\hline Well & 24 & 48 & 44 & 88 \\
\hline Enough & 12 & 24 & 6 & 12 \\
\hline Less & 14 & 28 & 0 & 0 \\
\hline \multicolumn{5}{|l|}{ Actions of Risti detection } \\
\hline Well & 8 & 16 & 48 & 96 \\
\hline Enough & 2 & 4 & 0 & 0 \\
\hline Less & 40 & 80 & 2 & 4 \\
\hline \multicolumn{5}{|l|}{ Skill of Risti detection } \\
\hline Well & 6 & 12 & 45 & 90 \\
\hline Enough & 4 & 8 & 3 & 6 \\
\hline Less & 40 & 80 & 2 & 4 \\
\hline
\end{tabular}

Table 3 shows that the level of knowledge of pregnant women in the control group. There was an increase in the variables of knowledge, attitudes, actions, and skills in early detection of pregnancy risk from pre-test to post-test. However, most of their actions were still in the poor category $(88 \%$ on the posttest), and the skills to do early detection of pregnancy risk independently were also largely lacking $(94 \%$ on the post-test).
Table 3: Knowledge, attitudes, actions, and skills for early detection of risk of pregnancy in the control group for pregnant women in Palu City, 2020

\begin{tabular}{lllll}
\hline Variables of control group & Pre-test & \multicolumn{3}{l}{ Post-test } \\
\cline { 2 - 5 } & $\mathrm{n}$ & $(\%)$ & $\mathrm{n}$ & $(\%)$ \\
\hline Knowledge about RISTI detection & & & & \\
$\quad$ Well & 11 & 22 & 11 & 22 \\
$\quad$ Enough & 16 & 32 & 16 & 32 \\
$\quad$ Less & 23 & 46 & 23 & 46 \\
Attitude toward Risti detection & & & & \\
$\quad$ Well & 20 & 40 & 19 & 38 \\
$\quad$ Enough & 6 & 32 & 17 & 34 \\
$\quad$ Less & 14 & 28 & 14 & 28 \\
Actions of Risti detection & & & & \\
$\quad$ Well & 7 & 14 & 4 & 8 \\
$\quad$ Enough & 1 & 2 & 2 & 4 \\
$\quad$ Less & 42 & 84 & 44 & 88 \\
Skill of Risti detection & & & & \\
$\quad$ Well & 2 & 4 & 2 & 4 \\
$\quad$ Enough & 2 & 4 & 1 & 2 \\
$\quad$ Less & 46 & 92 & 47 & 94 \\
\hline
\end{tabular}

\section{Bivariate analysis}

Table 4 shows that there was a significant difference in the level of knowledge of pregnant women about early detection of pregnancy between pre- and post-test $(p<0.05)$. Furthermore, attitudes of pregnant women toward early detection of pregnancy $(p<0.05)$, actions of pregnant women in early detection of pregnancy $(p<0.05)$, and skills of pregnant women in early detection of pregnancy $(p<0.05)$.

Table 4: Differences in knowledge, attitudes, actions, and skills for early detection of pregnancy risks in pregnant women in the intervention group in Palu City, 2020

\begin{tabular}{|c|c|c|c|c|c|c|}
\hline \multirow[t]{2}{*}{ Variable } & \multirow[t]{2}{*}{ Pre-test } & \multicolumn{3}{|l|}{ Post-test } & \multirow[t]{2}{*}{ Total } & \multirow[t]{2}{*}{$\mathrm{p}^{*}$} \\
\hline & & Well & Enough & Less & & \\
\hline Knowledge about & Well & $1(2 \%)$ & $1(2 \%)$ & $0(0 \%)$ & $2(4 \%)$ & \multirow[t]{4}{*}{0.000} \\
\hline \multirow[t]{3}{*}{ RIST/ detection } & Enough & $11(22 \%)$ & $12(24 \%)$ & $1(2 \%)$ & $24(48 \%)$ & \\
\hline & Less & $8(16 \%)$ & $14(28 \%)$ & $2(4 \%)$ & $24(48 \%)$ & \\
\hline & Total & $20(40 \%)$ & $27(54 \%)$ & $3(6 \%)$ & $50(100 \%)$ & \\
\hline \multirow{4}{*}{$\begin{array}{l}\text { Attitude toward Risti } \\
\text { detection }\end{array}$} & Well & $22(44 \%)$ & $2(4 \%)$ & $0(0 \%)$ & $24(48 \%)$ & \multirow{4}{*}{0.000} \\
\hline & Enough & $10(20 \%)$ & $2(4 \%)$ & $0(0 \%)$ & $12(24 \%)$ & \\
\hline & Less & $12(24 \%)$ & $2(4 \%)$ & $0(0 \%)$ & $14(28 \%)$ & \\
\hline & Total & $44(88 \%)$ & $6(12 \%)$ & $0(0 \%)$ & $50(100 \%)$ & \\
\hline \multirow{4}{*}{$\begin{array}{l}\text { Actions of Risti } \\
\text { detection }\end{array}$} & Well & $7(14 \%)$ & $0(0 \%)$ & $1(2 \%)$ & $8(16 \%)$ & \multirow[t]{4}{*}{0.000} \\
\hline & Enough & $2(4 \%)$ & $0(0 \%)$ & $0(0 \%)$ & $2(4 \%)$ & \\
\hline & Less & $39(78 \%)$ & $0(0 \%)$ & $1(2 \%)$ & $40(80 \%)$ & \\
\hline & Total & $48(96 \%)$ & $0(0 \%)$ & $2(4 \%)$ & $50(100 \%)$ & \\
\hline \multirow[t]{4}{*}{ Skill of Risti detection } & Well & $6(12 \%)$ & $0(0 \%)$ & $0(0 \%)$ & $6(12 \%)$ & \multirow[t]{4}{*}{0.000} \\
\hline & Enough & $4(8 \%)$ & $0(0 \%)$ & $0(0 \%)$ & $4(8 \%)$ & \\
\hline & Less & $35(70 \%)$ & $3(6 \%)$ & $2(4 \%)$ & $40(80 \%)$ & \\
\hline & Total & $45(90 \%)$ & $3(6 \%)$ & $2(4 \%)$ & $50(100 \%)$ & \\
\hline
\end{tabular}

Table 5 shows that there was no difference in the level of knowledge of pregnant women about early detection of pregnancy risk in the pre- and post-test results $(p>0.05)$. Furthermore, the attitudes of pregnant women toward early detection of pregnancy $(p>0.05)$, the actions of pregnant women in early detection pregnancy $(p>0.05)$, and the skills of pregnant women in early detection of pregnancy $(p>0.05)$.

Table 6 shows a comparison of the level of knowledge, attitudes, and actions of pregnant women regarding the early detection of pregnancy risk in the intervention group with the control group. The result turned out that there was a significant difference between both groups $(p<0.05)$ with a significant value between those two groups in terms of early detection of pregnancy risk, both on knowledge $(p<0.05)$, and 
Table 5: Differences in knowledge, attitudes, actions, and skills for early detection of pregnancy risks in pregnant women in the control group in Palu City, 2020

\begin{tabular}{|c|c|c|c|c|c|c|}
\hline \multirow{2}{*}{ Variable } & \multirow[t]{2}{*}{ Pre-test } & \multicolumn{3}{|l|}{ Post-test } & \multirow[t]{2}{*}{ Total } & \multirow[t]{2}{*}{$\mathrm{p}^{*}$} \\
\hline & & Well & Enough & Less & & \\
\hline Knowledge about & Well & $2(4 \%)$ & $0(0 \%)$ & $0(0 \%)$ & $2(4 \%)$ & 1.000 \\
\hline \multirow[t]{3}{*}{ RISTI detection } & Enough & $0(0 \%)$ & $22(44 \%)$ & $0(0 \%)$ & $22(44 \%)$ & \\
\hline & Less & $0(0 \%)$ & $0(0 \%)$ & $26(52 \%)$ & $26(52 \%)$ & \\
\hline & Total & $2(4 \%)$ & $22(44 \%)$ & 26 (52\%) & $50(100 \%)$ & \\
\hline \multirow{4}{*}{$\begin{array}{l}\text { Attitude toward Risti } \\
\text { detection }\end{array}$} & Well & $19(38 \%)$ & $1(2 \%)$ & $0(0 \%)$ & $20(40 \%)$ & 0.317 \\
\hline & Enough & $0(0 \%)$ & $16(32 \%)$ & $0(0 \%)$ & $16(32 \%)$ & \\
\hline & Less & $0(0 \%)$ & $0(0 \%)$ & $14(28 \%)$ & $14(28 \%)$ & \\
\hline & Total & $19(38 \%)$ & $17(34 \%)$ & $14(28 \%)$ & $100(50 \%)$ & \\
\hline \multirow{4}{*}{$\begin{array}{l}\text { Actions of Risti } \\
\text { detection }\end{array}$} & Well & $4(8 \%)$ & $1(2 \%)$ & $2(4 \%)$ & $7(14 \%)$ & 0.102 \\
\hline & Enough & $0(0 \%)$ & $1(2 \%)$ & $0(0 \%)$ & $1(2 \%)$ & \\
\hline & Less & $0(0 \%)$ & $0(0 \%)$ & $42(84 \%)$ & $42(84 \%)$ & \\
\hline & Total & $4(8 \%)$ & $2(4 \%)$ & $44(88 \%)$ & $50(100 \%)$ & \\
\hline \multirow{4}{*}{$\begin{array}{l}\text { Skill of Risti } \\
\text { detection }\end{array}$} & Well & $2(4 \%)$ & $0(0 \%)$ & $0(0 \%)$ & $2(4 \%)$ & 0.317 \\
\hline & Enough & $0(0 \%)$ & $1(2 \%)$ & $1(2 \%)$ & $2(4 \%)$ & \\
\hline & Less & $0(0 \%)$ & $0(0 \%)$ & $46(92 \%)$ & $46(92 \%)$ & \\
\hline & Total & $2(4 \%)$ & $1(2 \%)$ & $47(94 \%)$ & $50(100 \%)$ & \\
\hline
\end{tabular}

attitude $(p<0.05)$, measures $(p<0.05)$, and the skills of pregnant women in doing early detection of pregnancy risk independently $(p<0.05)$. This showed that the provision of modules and application of M.D-Risti in the intervention group had a significant effect on changes in knowledge, attitudes, actions, and skills of pregnant women in early detection of pregnancy risk compared to pregnant women who were not given intervention at all.

Table 6: Differences in knowledge, attitudes, actions, and skills for early detection of pregnancy risks in pregnant women in the intervention group and control group in Palu City, 2020

\begin{tabular}{lllllll}
\hline Variables & Control & \multicolumn{2}{l}{ Intervention } & Total & \multirow{2}{*}{$\mathrm{p}^{*}$} \\
\cline { 2 - 5 } & & Well & Enough & Less & & \\
\hline Knowledge about & Well & $1(2 \%)$ & $1(2 \%)$ & $0(0 \%)$ & $2(4 \%)$ & 0.000 \\
RISTI detection & Enough & $5(10 \%)$ & $16(32 \%)$ & $1(2 \%)$ & $22(44 \%)$ & \\
& Less & $14(28 \%)$ & $10(20 \%)$ & $2(4 \%)$ & $26(52 \%)$ & \\
& Total & $20(40 \%)$ & $27(54 \%)$ & $3(6 \%)$ & $50(100 \%)$ & \\
Attitude toward & Well & $18(36 \%)$ & $1(2 \%)$ & $0(0 \%)$ & $19(38 \%)$ & 0.000 \\
Risti detection & Enough & $13(26 \%)$ & $4(8 \%)$ & $0(0 \%)$ & $17(34 \%)$ & \\
& Less & $13(26 \%)$ & $1(2 \%)$ & $0(0 \%)$ & $14(28 \%)$ & \\
Actions of Risti & Total & $44(88 \%)$ & $6(12 \%)$ & $0(0 \%)$ & $50(100 \%)$ & \\
detection & Well & $4(8 \%)$ & $0(0 \%)$ & $0(0 \%)$ & $4(8 \%)$ & 0.000 \\
& Enough & $2(4 \%)$ & $0(0 \%)$ & $0(0 \%)$ & $2(4 \%)$ & \\
& Less & $42(84 \%)$ & $0(0 \%)$ & $2(4 \%)$ & $44(88 \%)$ & \\
Skill of Risti & Total & $48(96 \%)$ & $0(0 \%)$ & $2(4 \%)$ & $50(100 \%)$ & \\
detection & Well & $1(2 \%)$ & $1(2 \%)$ & $0(0 \%)$ & $2(4 \%)$ & 0.000 \\
& Enough & $1(2 \%)$ & $0(0 \%)$ & $0(0 \%)$ & $1(2 \%)$ & \\
& Less & $43(86 \%)$ & $2(4 \%)$ & $2(4 \%)$ & $47(94 \%)$ & \\
& Total & $45(90 \%)$ & $3(6 \%)$ & $2(4 \%)$ & $50(100 \%)$ & \\
\hline${ }^{*}$ Mann-Whitney test. & & & & & &
\end{tabular}

\section{Discussion}

Knowledge, attitudes, actions, and skills of pregnant women in early detection of risk of pregnancy before and after treatment in the intervention and control groups

The results of the study in the intervention group showed that there was an increase in knowledge, attitudes, actions, and skills for early detection of highrisk pregnancy from pre-test to post-test. Although most of the respondents' knowledge level was in a sufficient category, they have good attitudes, good actions, and good skills in the early detection of pregnancy. The results of the study in the control group showed no increase in the variables of knowledge, attitudes, actions, and skills in the early detection of pregnancy risk from pre-test to post-test. Even for the attitude and action variables, there was a decrease, most of which were in the less category.

Based on the results of other studies, it was revealed that the class of pregnant women had a significant effect on knowledge, the $p$-value was 0.027 , the class of pregnant women had no significant effect on attitudes with $a p=0.347$ and there was a significant effect. The effect of the class of pregnant women on the skills of pregnant women about the danger signs of second-trimester pregnancy $p=0.008$ [15]. The results of other studies also show that most of the respondents' awareness of high-risk pregnancy before being given health education was in the proper category $(55 \%)$, after being given health education to increase it to become good knowledge (65\%). There were differences in the level of knowledge before and after health education was given $(p=0.000)$. There was an increase in the knowledge of mothers about high-risk pregnancies after being given health education [16].

According to Notoatmodjo (1997), knowledge is the result of knowing and this occurs after a person senses a certain object. One of the variables that contribute to knowledge is the level of education [17]. According to Donelly (2010), education has an important role in determining human quality. Through education, humans are considered to gain knowledge, where the higher the education, the easier it is for someone to accept new things and to adapt to new things. However, it does not rule out that people who have low education have good knowledge and skills. Good knowledge will increase one's awareness, especially the awareness of pregnant women that early detection of pregnancy risks is part of the responsibility of pregnant women who are assisted in its implementation by midwives.

Newcomb, a social psychologist, states that attitude is a readiness or willingness to act and not an implementation of a particular motive [18]. In other words, the function of attitude is not yet an action (open reaction) or activity, but rather a predisposition to behavior (action) or closed reaction. Good knowledge is not always positively correlated with a good attitude, so that sometimes there is someone with good knowledge but has a bad attitude. Although generally research shows that knowledge is positively correlated with a positive person's attitude. In this study, although most of the respondents' knowledge was at a sufficient level $(60 \%)$, most of them had good attitudes $(88 \%)$, good action (96\%), and good skills (90\%).

Early detection is the netting and screening efforts implemented to find since the beginning of the risk factors that contribute to the emergence of complications in pregnancy. With early detection and good education, it is hoped that pregnant women will be able to take action or avoid and reduce risks and be able to prepare to respond effectively to disorders/ complications and diseases that commonly occur 
during pregnancy and childbirth. [19]. Early detection is screening for possible high risks or complications of pregnancy and providing information to mothers or the public so that they can take preventive measures.

Early detection carried out by midwives and then informed to pregnant women is often less effective. Pregnant women consider that early detection of high risks is the responsibility of the midwife for the benefit of the health program, not for the benefit of pregnant women. Moreover, the results of early detection in the form of a scorecard are stored at the Health Center (Puskesmas) by the midwife [11]. Therefore, one of the objectives of this study was to assess the knowledge, attitudes, actions, and skills of pregnant women in early detection of the high risk of pregnancy, after being given information and training on how pregnant women can detect their high risk of pregnancy independently using the application, especially when the pandemic situation.

\section{The effectiveness of module and} application of M.D-Risti in increasing knowledge, attitudes, actions, and skills of pregnant women in early detection of pregnancy risks

The researcher wanted to know the effectiveness of the provision of interventions (M.D-Risti modules and applications) on the knowledge, attitudes, actions, and skills of pregnant women in early detection of pregnancy risk independently. The researchers compared the research data in the intervention group with the control group. The results showed a significant difference between the two groups, both in knowledge $(p<0.05)$, attitude $(p<0.05)$, action $(p<0.05)$, and the skills $(p<0.05)$ of pregnant women in carrying out early detection of pregnancy risk independently. This shows that the provision of modules and application of M.D-Risti in the intervention group had a significant effect on changes in knowledge, attitudes, actions, and skills of pregnant women in early detection of pregnancy risk compared to pregnant women who were not given intervention at all.

The results of this study are in line with other studies where the system (SIDILAN) shows an increase in utilization compared to manual recording and is considered more comfortable to use and applied in general, and this application can quickly detect at-risk pregnant women who need to get an immediate referral to facilitate health workers/midwives, in particular, to prevent maternal and neonatal emergencies in their work area. The results of tests carried out generally showed a significant difference between early detection of high risk, manual reference systems on islands (103), and $p 0.001(p<0.05)$. Consequently, the app usability rate is higher than that of the manual [14].

In the current state of the COVID-19 pandemic, innovation is needed in health services, including maternal, and child health services. The results of data analysis on antenatal care coverage figures ( $\mathrm{K} 1$ and $\mathrm{K} 4$ ) in Central Sulawesi, especially in the city of Palu, found a decrease in these coverage figures. Since the first COVID case entered the city of Palu (26 March 2020), the number of COVID-19 in Central Sulawesi and Palu has increased significantly. Some districts fall into the red zone (high risk). Until the end of September 2020, there were three districts in Central Sulawesi that were included in the red zone. One of them is the city of Palu. Several Posyandu (Integrated Healthcare Centers) in Palu City cannot provide maximum service as before COVID-19. Likewise, the class of pregnant women who are routinely held every month when there is no COVID-19 pandemic so that the contact between midwives and pregnant women is limited. The $\mathrm{K} 1$ and K4 coverage rates decreased. Pregnancy risk factors are not detected properly, so the risk of pregnancy complications that lead to maternal death is higher.

The M.D-Risti application that can be accessed independently, done and the results can be seen by the coordinator of the midwife and the head of the Health Center (Puskesmas) as the admin will be able to help overcome this problem. The admin could access the results in the form of tables, graphs, and risk score figures which are presented in Figure 1. The admin could also find out which urban villages in their work area have low, high, and very high-risk pregnant women in Figure 2.

A high-risk pregnancy is a pregnancy that will cause greater harm and complications to both the mother and the fetus in the womb and can lead to death, illness, disability, discomfort, and dissatisfaction. Thus, to deal with pregnancy or high-risk fetuses, a proactive attitude must be taken, planning with promotive and preventive efforts. Until such time, the right and fast attitude must be taken to save the mother and the baby or only the mother should be chosen. Conditions that can increase the risk of maternal death are indirectly referred to as risk factors, the more risk factors found in pregnancy, the higher the risk. Complications during pregnancy can be categorized as a risk for pregnancy, as many as $90 \%$ of the causes of death occur due to unexpected obstetric complications during pregnancy, during delivery, or postpartum, and $15 \%$ of pregnancies are thought to be high risk and can harm the mother and the fetus [20].

Pregnancy at risk is divided into three criteria which are outlined in the form of numbers or scores. The round numbers used in the assessment are 2, 4, and 8 for each variable and then added up to the final total score. Based on the total score of pregnancy at risk, it is divided into (1) low-risk pregnancy (LRP), where all pregnant women are at risk for their pregnancy. For pregnant women with low-risk pregnancies, the total score is 2, namely, without any problems or risk factors. Deliveries with low-risk pregnancies are carried out normally with the mother and baby healthy, not referred to and able to be assisted by midwives; (2) high-risk pregnancy (HRP): A high-risk pregnancy with a total 




Figure 1: Figures for the risk score for pregnancy risk detection on the M.D-Risti application



Figure 2: Risk detection for pregnant women by urban village work area on the M.D-Risti application

score of $6-10$, there is one or more causes of problems in pregnancy, both from the mother and the baby in the womb, which has an unfavorable impact on both the mother and the future baby. The HRP category has emergency but not emergency risks; (3) very high-risk pregnancy (VHRP): Very high-risk pregnancy with a total score of $\geq 12$. Pregnant women with two or more risk factors increase and require timeliness in carrying out referral actions and adequate delivery assistance at the hospital by a specialist. The results showed that VHRP is a group with the highest risk of causes of maternal death [21], [22].

By the M.D-Risti application and guided by modules, pregnant women can do early detection of their pregnancy risk independently, can find out the risk score, can know what to do (in the application there is an educational feature, according to the level of risk), and who most importantly there is the responsibility to carry out the management of her pregnancy adequately. Likewise, the midwife at the Health Center (Puskesmas), the head of the Health Centre (Puskesmas), and the head of the Palu City Health office can monitor pregnant women with the level of risk. They can monitor each village, each district, or each Health Center (Puskesmas) so that you can quickly determine preventive steps to prevent pregnancy complications.

In the short-term, this M.D-Risti application is one of the solutions during the Covid-19 pandemic. 
In the long-term, this application can be used by all Health Centre (Puskesmas) in Palu city to help monitor pregnancy risk more quickly.

\section{Conclusion}

Based on the results of the study, it was found that there were differences in knowledge, attitudes, actions, and skills of pregnant women in early detection of pregnancy risk before and after being given the intervention module and application of M.D-Risti and there were significant differences between the control group and the intervention group. The provision of modules and the application of M.D-Risti to the intervention group had a significant effect on changes in knowledge, attitudes, actions, and skills of pregnant women in early detection of pregnancy risk compared to pregnant women who were not given intervention at all.

\section{Acknowledgment}

Thanks to all those who helped in this research, especially the head of the Health Centre, midwives, other medical personnel, and thanks to the respondents who were involved.

\section{References}

1. World Health Organization. World Health Statistics 2016: Monitoring Health for the SDGs Sustainable Development Goals. Geneva: World Health Organization; 2016. https://doi. org/10.26719/2016.22.5.350

2. Misra DP, Grason H. Achieving safe motherhood: Applying a life course and multiple determinants perinatal health framework in public health. Womens Health Issues. 2006;16(4):159-75. https://doi.org/10.1016/j.whi.2006.02.006 PMid:16920521

3. Kemenkes RI. Profil Data Kesehatan Indonesia Tahun 2011. Jakarta: Kementerian Kesehatan Republik Indonesia; 2012.

4. World Health Organization. State of Inequality: Reproductive Maternal Newborn and Child Health: Interactive Visualization of Health Data. Geneva: World Health Organization; 2015.

5. Saifuddin $A B$. Issues in training for essential maternal health care in Indonesia. Med J Indones. 1997;6(3):140-8. https://doi. org/10.13181/mji.v6i3.817
6. Depkes RI. Pedoman Pelayanan Antenatal Terpadu. Jakarta: Direktorat Jenderal Bina Kesehatan Masyarakat Direktorat Bina Kesehatan Ibu; 2010.

7. Chamberlain G. ABC of Antenatal Care. London: BMJ Books; 2002.

8. Marmi SS. Asuhan Kebidanan Pada Masa Antenatal. Yoyakarta: Pal Mall; 2011.

9. Manuaba IB, Manuaba IC, Manuaba I. Pengantar Kuliah Obstetri. Jakarta: EGC; 2007. p. 450-5.

10. Sirua NH.Gambaran Faktor-Faktor Risiko Kehamilan Berdasarkan Kartu Skor Poedji Rochjati (KSPR) di Pos Kesehatan Kelurahan Mojo, Surabaya Periode Januari-Juni 2017. Indonesia: Universitas Airlangga; 2018. https://doi. org/10.20473/mog.v23i3.2073

11. Widarta GD, Laksana MA, Sulistyono A, Purnomo W. Early Detection of Risk for Pregnant Women with the Poedji Rochjati Score Card and Prevention of the Factor Four Too Late. Majalah Obstet Ginekol. 2015;23(1):28-32. https://doi.org/10.20473/ mog.v23i1.2100 12.

12. Menendez C, Gonzalez R, Donnay F, Leke RG. Avoiding indirect effects of COVID-19 on maternal and child health. Lancet Glob Health. 2020;8(7):e863-4. https://doi.org/10.1016/ s2214-109x(20)30239-4 PMid:32413281

13. Shikuku D, Nyaoke I, Gichuru S, Maina O, Eyinda M, Godia P, et al. Early Indirect Impact of COVID-19 Pandemic on Utilization and Outcomes of Reproductive, Maternal, Newborn, Child and Adolescent Health Services in Kenya, medRxiv; 2020. https:// doi.org/10.1101/2020.09.09.20191247

14. Harindra LD. Web-based application development of early detection of high-risk maternal referral system in the islands region (SIDILAN) in South Bangka regency. Indian J Public Health Res Dev. 2020;11(7):301-7.

15. Sugiartini DK. The influence of pregnant women classes on knowledge, attitudes and skills of conducting early detection of danger signs during the second trimester of pregnancy in buleleng regency. J Qual Public Health. 2020;3(2):564-74. https://doi.org/10.30994/jgph.v3i2.106

16. Zakiyya A, Rusmini R, Sartika QL. Enhancing the pregnant women knowledge through health education about high-risk pregnancy. J Kesehatan Anak. 2019;13(1):63-73. DOI: https:// doi.org/10.29238/kia.v13i1.415.

17. Notoatmodjo S. Pengantar Pendidikan. Kesehatan dan IImu Perilaku Kesehatan. Yogyakarta: Andi Offset; 1997.

18. Newcomb TM. Psikologi Social, Diponegoro; 1985.

19. Rukiyah AY, Yulianti L. Asuhan Kebidanan IV (Patologi Kebidanan). Jakarta: Trans Info Media; 2010.

20. Unicef, Ringkasan Kajian Kesehatan Ibu dan Anak. Jakarta: Unicef Indonesia; 2012.

21. Azinar M, Wahyuningsih AS. Pos Keluarga Siaga Untuk Risk Mapping dan Micro Counseling Kehamilan Risiko Tinggi di Daerah Pedesaan Kabupaten Kendal. Vol. 16. Rekayasa: Jurnal Penerapan Teknologi dan Pembelajaran; 2019. https:// doi.org/10.15294/rekayasa.v16i2.17559

22. Anggraeny FT, Muttaqin F, Munir MS. Modeled Early Detection of Pregnancy Risk Based on Poedji Rochjati Score Card Using Relief and Neural Network, Proceedings. Vol. 1. Chennai: IJCST; 2017. Available from: http://www.ojs.pnb.ac.id/index.php/ proceedings/article/view/920. [Last accessed on 2020 Oct 07]. 